\title{
Empowering rare disease patients through patient education: the new BehçeTalk programme
}

\author{
D. Marinello ${ }^{1}$, A. Del Bianco ${ }^{2}$, A. Manzo ${ }^{3}$, M. Mosca $^{1}$ and R. Talarico ${ }^{*^{*}}$ (D)
}

\begin{abstract}
Background: Educating patients and caregivers on their disease can improve their knowledge and promote the active involvement in the therapeutic decision-making process. Naturally, patient education programmes are critically important in rare systemic autoimmune diseases, where relevant knowledge and expertise still remain scattered. Behçet's disease (BD) represents a challenging rare condition, characterized by a variable spectrum of disease profile and a relapsing course.

Results: Recently, BehçeTalk, an educational programme tailored for BD patients, families and caregivers with, was launched. BehçeTalk, entirely co-designed with BD patients, is offering educational on-line webinars on different aspects of the disease, as well support groups for patients and caregivers coordinated by a psychologist with specific expertise in BD.
\end{abstract}

Conclusions: The therapeutical management of $\mathrm{BD}$ is often challenging and frequently includes off-label treatments. Considering the specificities of $\mathrm{BD}$, providing a specific education on the disease to patients will lead to empower them in being part of the decision-making processes, in the self-management and in improving their quality of life.

Keywords: Educational programme, Behçet's disease, Patients' empowerment

Sirs,

Patients' education can be considered a milestone of the patients' empowerment, in terms of knowledge and awareness on the disease and of rights and responsibility of the patient in the care process [1]. Educating patients and caregivers on their disease can improve their knowledge and promote the active involvement in the therapeutic decision-making process [2-4]. Naturally, patient education programmes are critically important in rare systemic autoimmune diseases, where relevant knowledge and expertise still remain scattered.

\footnotetext{
*Correspondence: sara.talarico76@gmail.com

${ }^{1}$ Azienda Ospedaliero Universitaria Pisana, Rheumatology Unit, University of Pisa, Via Roma 67, 56126 Pisa, Italy

Full list of author information is available at the end of the article
}

Behçet's disease (BD) represents a challenging rare condition, characterized by a variable spectrum of disease profile and a relapsing course [5]. The therapeutical management of BD is often challenging and frequently includes off-label treatments. Considering the specificities of $\mathrm{BD}$, providing a specific education on the disease to patients will lead to empower them in being part of the decision-making processes, in the self-management and in improving their quality of life.

Recently, BehçeTalk, an educational program tailored for patients, families and caregivers living with BD, was launched in Italy [6]; the initiative was promoted by the Behçet Clinic of Pisa together with the the Italian patients' association for BD (SIMBA). BehçeTalk is offering educational on-line webinars on different aspects of the disease, as well support groups for patients and 
caregivers coordinated by a psychologist with specific expertise in BD.

BehçeTalk was entirely developed in co-design with BD patients, caregivers and patients' representatives, by means of multisteps agreement on the the unmet nedds and relative topics to be covered. Involving patients and caregivers in the identification of each topic ensured that the programme is tailored to what patients consider important. Each webinar is presented in a standard format in which different experts in BD focus the talk on specific aspect(s) of the disease in the first section of the webinar; furthermore, a session questions and answers represents the second section of the talk. Some of the topics addressed in the programme include quality of life, workability, sexuality, self-management, adherence to treatment, pregnancy and family planning. Moreover, some of the major points to be discussed in the patients' support groups are related to the ability to heal the "wound" resulting from the BD diagnosis, the perception and happiness in daily life, interpersonal and social relationships, while for $\mathrm{BD}$ caregivers being parents/partner/siblings of a BD patient represent the most frequent challenge.

The BehçetTalk educational program aims to create greater awareness of the disease and of its impact on the daily life of patients, partners, caregivers and family members. Being informed and acquiring a good level of awareness helps patients living better lives, but also helps doctors and patients in improving the management of the disease.

The more clearly $\mathrm{BD}$ is understood, the more likely $\mathrm{BD}$ patients and their caregivers can be comfortable with their disease and their care (Additional file 1).

\section{Abbreviations}

BD: Behçet's disease; S.I.M.B.A: Associazione Italiana Sindrome e Malattia di Behçet.

\section{Supplementary Information}

The online version contains supplementary material available at https://doi. org/10.1186/s41927-022-00247-1.

Additional file 1. Online the educational programme "BehçeTalk".

\section{Acknowledgements}

The authors wish to thank the Italian Patients association for Behçet's disease (SIMBA OdV) and all the individual patients who have contributed to the creation of the educational programme BehçeTalk.

\section{Authors' contributions}

DM, ADB, AM, MM and RT conceived the letter; All authors repeatedly edited the manuscript and approved the final version.

\section{Funding}

The Educational program BehçeTalk was supported by a donation from the Italian Patients association for Behçet's disease (SIMBA OdV).
Availability of data and materials

The material related to the educational program BehçeTalk are available on the website https://behcetclinic-pisa.it/en/behcet-talk-eng/.

\section{Declarations}

Ethics approval and consent to participate

Not applicable.

\section{Consent for publication}

Not applicable.

\section{Competing interests}

The authors declare that they have no competing interests.

\section{Author details}

${ }^{1}$ Azienda Ospedaliero Universitaria Pisana, Rheumatology Unit, University of Pisa, Via Roma 67, 56126 Pisa, Italy. ${ }^{2}$ Associazione S.I.M.B.A (Associazione Italiana Sindrome e Malattia di Behçet), Pontedera, Italy. ${ }^{3}$ Rome, Italy.

Received: 28 September 2021 Accepted: 27 January 2022

Published online: 28 February 2022

\section{References}

1. De Santis M, Hervas C, Weinman A, Bosi G, Bottarelli V. Patient empowerment of people living with rare diseases. Its contribution to sustainable and resilient healthcare systems. Ann Ist Super Sanita. 2019;55(3):283-91. https://doi.org/10.4415/ANN_19_03_15.

2. Ayméé $\mathrm{S}$, Kole A, Groft $\mathrm{S}$. Empowerment of patients: lessons from the rare diseases community. Lancet. 2008;371(9629):2048-51. https://doi.org/10. 1016/S0140-6736(08)60875-2.

3. Nikiphorou E, Alunno A, Carmona L, Kouloumas M, Bijlsma J, Cutolo M. Patient-physician collaboration in rheumatology: a necessity. RMD Open. 2017;3(1): e000499. https://doi.org/10.1136/rmdopen-2017-000499.PMID: 29152329.

4. Talarico R, Marinello D, Manzo A, Cannizzo S, Palla I, Ticciati S, Gaglioti A, Trieste L, Pisa L, Badalamenti L, Randisi G, Del Bianco A, Lorenzoni V, Turchetti G, Mosca M. Being a caregiver of a Behçet's syndrome patient: challenges and perspectives during a complex journey. Orphanet J Rare Dis. 2021;16(1):436.

5. Hatemi G, Seyahi E, Fresko I, Talarico R, Hamuryudan V. One year in review 2020: Behçet's syndrome. Clin Exp Rheumatol. 2020;127(5):3-10.

6. BehçeTalk: Educational program for patients, family members and caregivers of people living with Behçet's disease. https://behcetclinic-pisa.it/ en/behcet-talk-eng/. Accessed July 2021.

\section{Publisher's Note}

Springer Nature remains neutral with regard to jurisdictional claims in published maps and institutional affiliations.

Ready to submit your research? Choose BMC and benefit from:

- fast, convenient online submission

- thorough peer review by experienced researchers in your field

- rapid publication on acceptance

- support for research data, including large and complex data types

- gold Open Access which fosters wider collaboration and increased citations

- maximum visibility for your research: over 100M website views per year

At BMC, research is always in progress.

Learn more biomedcentral.com/submissions 